\title{
Understanding and Measuring Tourist Destination Images
}

\author{
Olivia H. Jenkins* \\ Australian Housing and Urban Research Institute, University of Queensland, St Lucia, QLD 4072, \\ Australia
}

\section{ABSTRACT}

A destination image is 'the expression of all objective knowledge, impressions, prejudice, imaginations, and emotional thoughts an individual or group might have of a particular place' (Lawson and Baud Bovy, 1977). Destination images influence a tourist's travel decision-making, cognition and behaviour at a destination as well as satisfaction levels and recollection of the experience. This paper looks at the concept of tourist destination images and how destination image research has been approached from different academic disciplines and by practitioners such as tourism marketers.

In particular, different techniques for the measurement of a tourist's destination images are reviewed and the dominance of structured, word-based approaches is highlighted. This paper adds to previous work that has listed the main attributes used in image studies by including recent studies, many of which are Australian. In the paper it is argued that to provide valid image research, a preliminary phase of qualitative research is important in order to distil the constructs relevant to the population being studied. Construct elicitation techniques, such as free-elicitation, interactive interviews and focus group interviews, are discussed along with new techniques that include the visual aspect of image, such as photoelicitation. Copyright (C) 1999 John Wiley \& Sons, Ltd.

\footnotetext{
* Correspondence to: O. H. Jenkins, Australian Housing and Urban Research Institute, University of Queensland, St Lucia, QLD 4072, Australia.

Email: o.jenkins@mailbox.uq.edu.au
}

Received 20 September 1997; Revised 22 November 1997; accepted 2 February 1998

Keywords: tourist destination image; construct elicitation; image measurement; content analysis; photo-elicitation.

\section{WHAT ARE TOURIST DESTINATION IMAGES?}

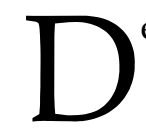

etermining an exact meaning of the term 'tourist destination image' is problematic. The term has been used in a variety of contexts, including those pertaining to the destination images projected by tourism promoters, the publicly held or 'stereotype' image of destinations and the destination images held by individuals. Following a comprehensive study of the definitions provided in the major destination-image measurement studies, Echtner and Ritchie (1991) note that many of the definitions used in previous studies are quite vague. At the heart of the definitional dilemma is the understanding of the term 'image'. As Pearce (1988, p. 162) comments 'image is one of those terms that won't go away ... a term with vague and shifting meanings'. Image is a term that has already been used differently in a large number of contexts and disciplines, thus creating different meanings. In psychology, 'image' tends to refer to a visual representation, whereas in behavioural geography the concept of 'image' is more holistic and it includes all of the associated impressions, knowledge, emotions, values and beliefs. Definitions from marketing, however, point to the attributes that underlie image and relate image to consumer behaviour.

Copyright (C) 1999 John Wiley \& Sons, Ltd. 
The definition for tourist destination image most commonly cited in research is that by Crompton (1979, p. 18) 'the sum of beliefs, ideas and impressions that a person has of a destination'. This definition relates to the individual, whereas other definitions acknowledge that images can be shared by groups of people. From a marketing point of view, it is important to understand those aspects of image that are held in common with other members of a particular group. This understanding affords the segmentation of markets and facilitates the formulation of marketing strategies. For these reasons, the definition by Lawson and Baud Bovy (1977), which encompasses both the personal images and the stereotyped images shared by groups, is chosen for this paper. They define destination image as:

the expression of all objective knowledge, impressions, prejudice, imaginations, and emotional thoughts an individual or group might have of a particular place.

\section{Why study tourist destination images?}

Tourist destination images are important because they influence both the decisionmaking behaviour of potential tourists (Mayo, 1973; Crompton, 1979) and the levels of satisfaction regarding the tourist experience (Chon, 1992). As Mayo (1975, p. 15) states in his article, the image of a destination area is a critical factor in a tourist's destination choice process. However, whether an image is a true representation of what any given region has to offer the tourist is less important than the mere existence of the image in the mind of the person. Whynne-Hammond (1985) takes this idea further stating that 'perceptions of foreign countries and their inhabitants may be wildly inaccurate'. However, probing destination images is an immensely important exercise because action proceeds on the basis of such subjective reality (Mercer, 1971, p. 264).

Marketers are interested in the concept of tourist destination image mainly because it relates to decision-making and sales of tourist products and services. According to MacInnis and Price (1987), imagery pervades the whole consumption experience. Before purchase,

Copyright (C) 1999 John Wiley \& Sons, Ltd. vicarious consumption may take place through imagery. During consumption, imagery can add value and increase satisfaction. After consumption, imagery can have a reconstructive role in which a person relives the experience via memories and vacation souvenirs. Understanding the differing images that visitors and non-visitors have of a destination is invaluable, enabling the salient attributes of the naive image and the re-evaluated image to be incorporated into tourism marketing planning (Selby and Morgan, 1996, p. 288). Marketers can also use imagery to increase remembered satisfaction and to encourage repeat purchases of holidays.

National tourist organisations, such as the Australian Tourist Commission (ATC), track the images held by potential visitors in the international marketplace. Such tracking studies and market segmentation analyses are used in the design of their promotional campaigns. Results of recent studies show that, internationally, Australia commands a very positive position in terms of travel desire compared with other destinations. However, image assessment alone will not guarantee success in new markets because other variables (e.g. access, prices and distance) may be more important in the tourist's overall decision-making process (Ahmed, 1991). There is a large amount of marketing literature that deals with destination decision-making and tourist demand (see Pizam et al., 1978; Van Raaj and Francken, 1984, Woodside and Lyonski, 1989), but it is beyond the scope of this paper to conduct a detailed discussion of this area.

\section{IMAGE FORMATION}

Each person's image of a particular place is unique, comprising their own memories, associations and imaginations of a particular place (Jenkins and McArthur, 1996, p. 11). Stabler (1988) divides the factors influencing the formation of a consumers' destination image into demand and supply factors. The demand factors roughly correspond with Gunn's organic image formation (discussed below), whereas the supply factors correspond to induced image formation. Figure 1 summarises these demand and supply factors.

Various researchers have investigated the

Int. J. Tourism Res. 1, 1-15 (1999) 


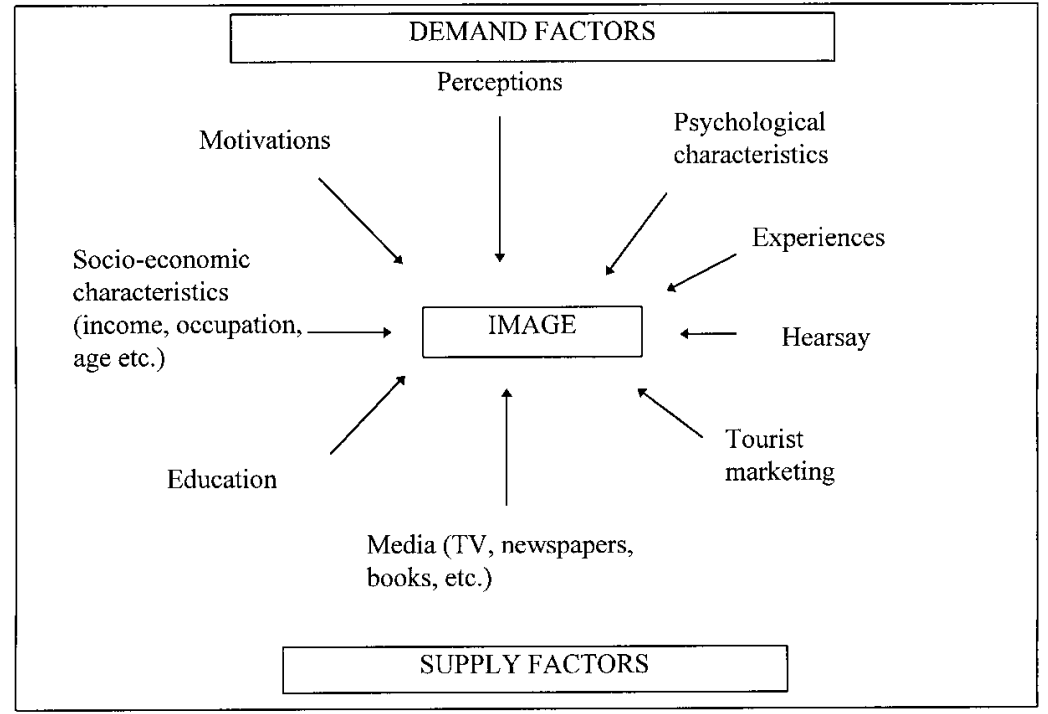

Figure 1. Factors influencing the formation of consumers' tourist image (source: Stabler, 1988).

factors influencing image formation. For example, Hunt (1975) and Scott et al. (1978) showed that destination image formation is determined partly by distance from the destination, because people are more likely to have visited the destinations near their homes and to have been exposed to information about them through the media and from friends and relatives. They concluded that people are likely to have stronger and more realistic images of a destination if it is near their home. Nolan (1976) investigated the sources of travel information used by domestic tourists in the United States of America. He found that the source of travel information used most frequently was the advice of friends and relatives, followed by guidebooks and commercial tourist information, then promotional publications. In terms of the credibility of travel information sources, guidebooks were rated highest, whereas government services by the State and the advice of friends of relatives were rated most informative. Nolan also measured 'objectivity' of the travel information sources by asking respondents to rate whether the sources were biased/unbiased, and inferred from the results that an overall bias in the communication of travel information (especially travel brochures) was recognised by the respondents. Despite recent studies (Phelps,

Copyright (C) 1999 John Wiley \& Sons, Ltd.
1986; Stabler, 1988; Chon, 1991, 1992; Echtner and Ritchie, 1991; Botterill and Crompton, 1996; Selby and Morgan, 1996), the process of image formation is not well understood and a theoretical framework for understanding it is needed.

In the initial development stage of constructing a theoretical framework, Gunn's (1972) seven-stage theory is useful (see Figure 2). The theory involves a constant building and modification of images, which are conceived as being made up of organic or naive nontourist information about the destination (e.g. from television documentaries, books, school lessons and stories of friends' experiences), induced or promoted information (e.g. travel brochures, publicity and advertisements) and modified induced images, which are the result of personal experience of the destination.

Stage theory implies that the images held by potential visitors, non-visitors and returned visitors will differ (Gunn, 1972). There is support for this theory in the results of several studies showing that images held by returned visitors tend to be more realistic, complex and differentiated (Pearce, 1982, 1988; Chon, 1990, 1992). In contrast, Phelps (1986, p. 172) and Narayana (1976) found that images of a destination may fade or revert over time, especially if intervening visits to other similar

Int. J. Tourism Res. 1, 1-15 (1999) 


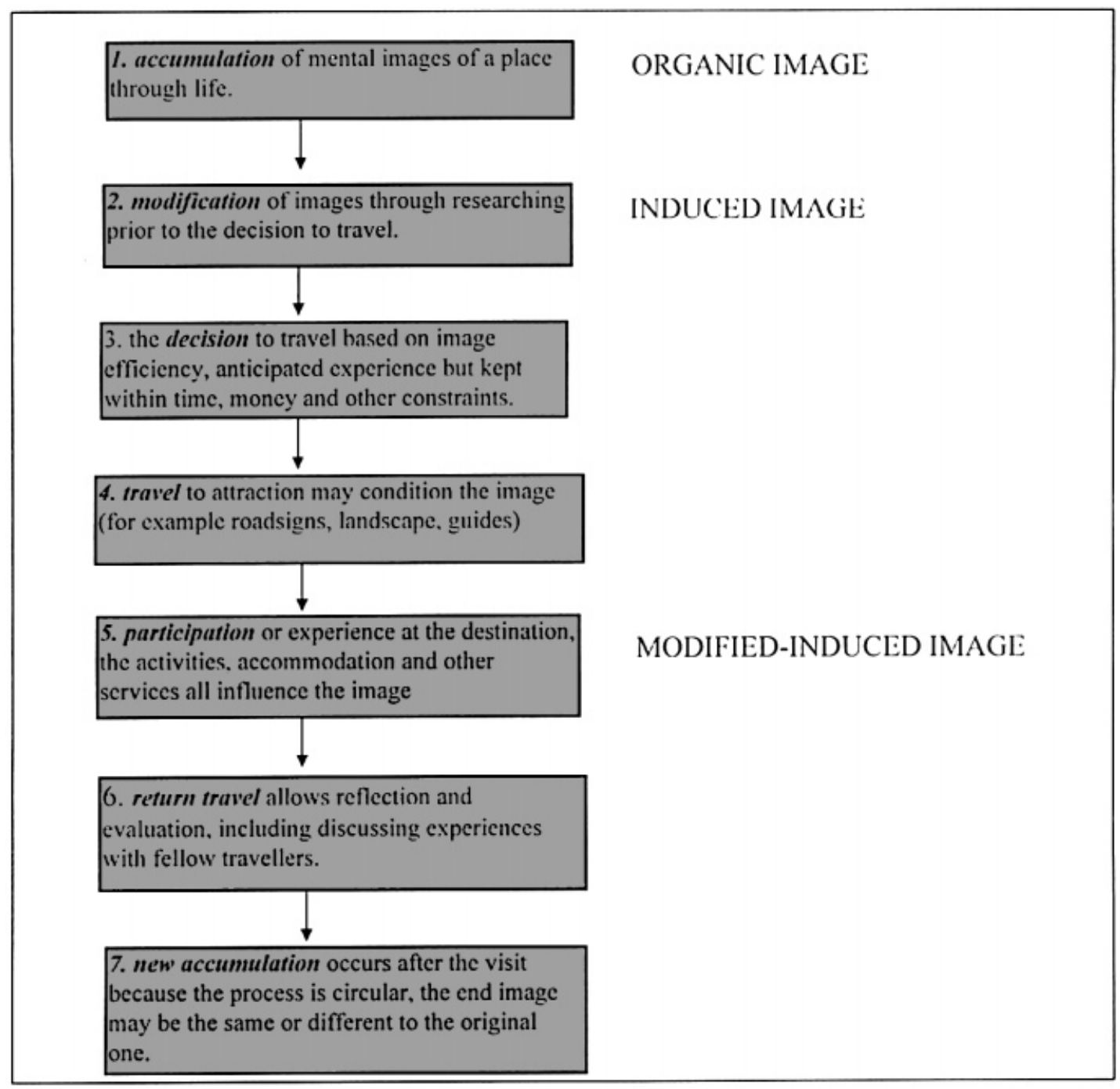

Figure 2. Stage-theories of destination image (source: Gunn, 1972, p. 120).

places confuse the memory. In Phelps' study, first-time and returning tourists to two new 'urbanizacione' Menorcan resorts were asked whether they expected their resort to be close to or part of a traditional Menorcan town or village. The two resorts are described in nearly all of the tourist brochures as 'traditional' or 'traditionally-styled', whereas in reality they were constructed recently. Both first-time and repeat tourists were found to be more likely to expect a traditional settlement, indicating that for repeat tourists the public image of a destination may actually be more persuasive than personal observation (Phelps, 1986, p. 174). A somewhat similar result was found by

Copyright (C) 1999 John Wiley \& Sons, Ltd.
Jenkins (1993, p. 81) in an Australian study of tourist perceptions of the Great Barrier Reef. Tourists who had visited the reef were asked to choose from a group of seven images the one that best matched their personal image of the Reef. The image chosen most commonly was an aerial photograph of the reef, as it is usually portrayed in tourist brochures, rather than a close-up view of coral, snorkelling, diving or boat trips, as it was more commonly experienced by the tourists themselves.

Chon (1992) studied the effects of a mismatch between the image and expectations about a destination and the actual experience of that destination and related this to models of 


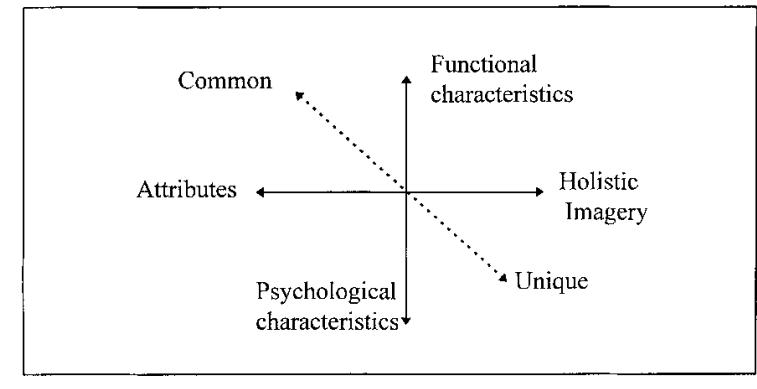

Figure 3. The components of destination image (source: Echtner and Ritchie, 1991).

buyer behaviour. She found that a positive image and positive travel experience will result in a moderately positive evaluation of a destination, whereas a negative image and a positive experience will result in a highly positive evaluation of a destination. The most negative evaluation will result from a positive image and negative experience. Although the experiential dimension of leisure and tourism trips has not been widely explored (Botterill and Crompton, 1996, p. 57), visitor expectations and reactions are increasingly seen as important because they primarily reflect tourists' cognitions, satisfaction and emotional reactions to a specific tourist venue (Ross, 1993).

\section{THE COMPONENTS OF DESTINATION IMAGE}

What are the important components or dimensions of destination image and how do people structure their understanding of destinations? Mayo (1975) examined regional tourist images of National Parks in North America and found that there are three basic dimensions of holiday destination images: scenery, congestion and climate. Like most tourist destination studies, Mayo's dimensions focus on physical or functional characteristics that are directly observable or measurable, for example, prices, size, and climate. Few studies have attempted to include the less tangible components of destination image or the difficult-to-measure psychological characteristics, such as the atmosphere or romance of the setting (Echtner and Ritchie, 1991). Ross (1994, p. 78) comments that

Copyright (C) 1999 John Wiley \& Sons, Ltd. the only psychological variable measured in the majority of studies is 'friendliness' of locals.

The common/unique dimension of destination image presented by Echtner and Ritchie (1991) (see Figure 3) is also often overlooked. This is surprising because much of tourism has to do with going somewhere unique or at least different to one's everyday surroundings. Common functional attributes include traits by which most destinations can be compared (e.g. price, climate, types of accommodation). Unique functional attributes consist of the icons and special events that form part of a destination image, such as the Sydney Harbour Bridge or the Glastonbury music festival. Common psychological or abstract attributes consist of the friendliness of the locals, notoriety or beauty of the landscape, whereas unique psychological attributes include feelings associated with places of religious pilgrimage or places associated with some historic event.

One of the basic problems of tourist destination image research is that destination images are 'holistic' representations of a place and that in attempting to measure them, researchers are compelled to look at the parts or attributes singularly. Some aspects of image, however, such as the aura or atmosphere, are not able to be broken down. Echtner and Ritchie (1991) overcome this problem by proposing a model that includes attribute-holistic as one of three dimensions. In this way, those parts of destination image that can be broken down into attributes are captured, as are the total, holistic impressions. At one end of the dimension are functional and psychological attributes, and at the other end are the functional and psychological holistic images concerning the overall impressions, the atmosphere or mood. Figure 3 shows their model, which should be envisioned in three dimensions: attribute/holistic, functional/psychological and common/unique.

\section{MEASURING DESTINATION IMAGES}

The failure of most studies to address the holistic components of destination image is related to the methods used by researchers (Echtner and Ritchie, 1991). There has been a strong preference for structured methods that

Int. J. Tourism Res. 1, 1-15 (1999) 
Table 1. Methods used in destination image research: structured versus unstructured (after Echtner and Ritchie, 1991)

\begin{tabular}{|c|c|c|}
\hline & Structured & Unstructured \\
\hline Description & $\begin{array}{l}\text { Various common image attributes are } \\
\text { specified and incorporated into a } \\
\text { standardised instrument and the } \\
\text { respondent rates each destination on each } \\
\text { of the attributes, resulting in an 'image } \\
\text { profile' }\end{array}$ & $\begin{array}{l}\text { The respondent is allowed to freely } \\
\text { describe his or her impressions of the } \\
\text { destination. Data are gathered from a } \\
\text { number of respondents. Sorting and } \\
\text { categorisation techniques are then used to } \\
\text { determine the 'image dimensions' }\end{array}$ \\
\hline Techniques & $\begin{array}{l}\text { Usually a set of semantic differential or } \\
\text { Likert type scales }\end{array}$ & $\begin{array}{l}\text { Focus groups, open-ended survey } \\
\text { questions, content analysis, repertory grid. }\end{array}$ \\
\hline Advantages & $\begin{array}{l}\text {-Easy to administer } \\
\text { - Simple to code } \\
\text { - Results easy to analyse using } \\
\text { sophisticated statistical techniques } \\
\text { - Facilitates comparisons between } \\
\text { destinations }\end{array}$ & $\begin{array}{l}\text { - Conducive to measuring the holistic } \\
\text { components of destination image } \\
\text { - Reduces interviewer bias } \\
\text { - Reduces likelihood of missing important } \\
\text { image dimensions or components }\end{array}$ \\
\hline Disadvantages & $\begin{array}{l}\text { - Does not incorporate holistic aspects of } \\
\text { image } \\
\text {-Attribute focused - that is, it forces the } \\
\text { respondent to think about the product } \\
\text { image in terms of the attributes specified } \\
\text { - The completeness of structured methods } \\
\text { can be variable - it is possible to miss } \\
\text { dimensions. }\end{array}$ & $\begin{array}{l}\text { - Level of detail provided by respondents is } \\
\text { highly variable } \\
\text { - Statistical analyses of the results are } \\
\text { limited } \\
\text { - Comparative analyses are not facilitated. }\end{array}$ \\
\hline
\end{tabular}

concentrate on the attribute component of destination image. The use of structured methods, such as Likert and semantic differential scales, requires an individual to rate a set of pre-determined attributes subjectively, or to characterise stimuli using standardised rating scales. Average ratings, multidimensional scaling or factor analysis are used to reduce the semantic scores to a smaller number of independent underlying perceptual dimensions. Because this type of procedure involves an a priori list of attributes to which an individual is supposed to respond, it might be relatively unreliable (Timmermans et al., 1982, p. 191). Unless care is taken compiling the list of attributes, some or all of these attributes might be totally unimportant to the individual, or important attributes may be missing. The advantages and disadvantages of structured and unstructured methods are compared in Table 1.

The dominance of structured techniques in Copyright (C) 1999 John Wiley \& Sons, Ltd. image research, especially those relying on word-based scales, has also led to a concentration on verbal over visual techniques in research. Pearce and Black (1996, p. 419) note that tourism researchers have 'yet to incorporate the visual domain into the methodological armoury of their own research practices' and that, as academics, 'our own familiarity with texts and words predisposes us to use these forms of presentation in our studies; a practice that may well be out of step with the experiences of an increasing number of visitors whose world is increasingly dominated by visual images'. Researchers need to begin to think creatively about using maps and photographs to aid visitor recall and generate richer data (Pearce and Black, 1996, p. 420). Pearce cites Craik (1971), who wrote that the determination of the 'media of representation' (that is how an environment should be presented to respondents) is one of the critical methodological considerations in the study of people and

Int. J. Tourism Res. 1, 1-15 (1999) 


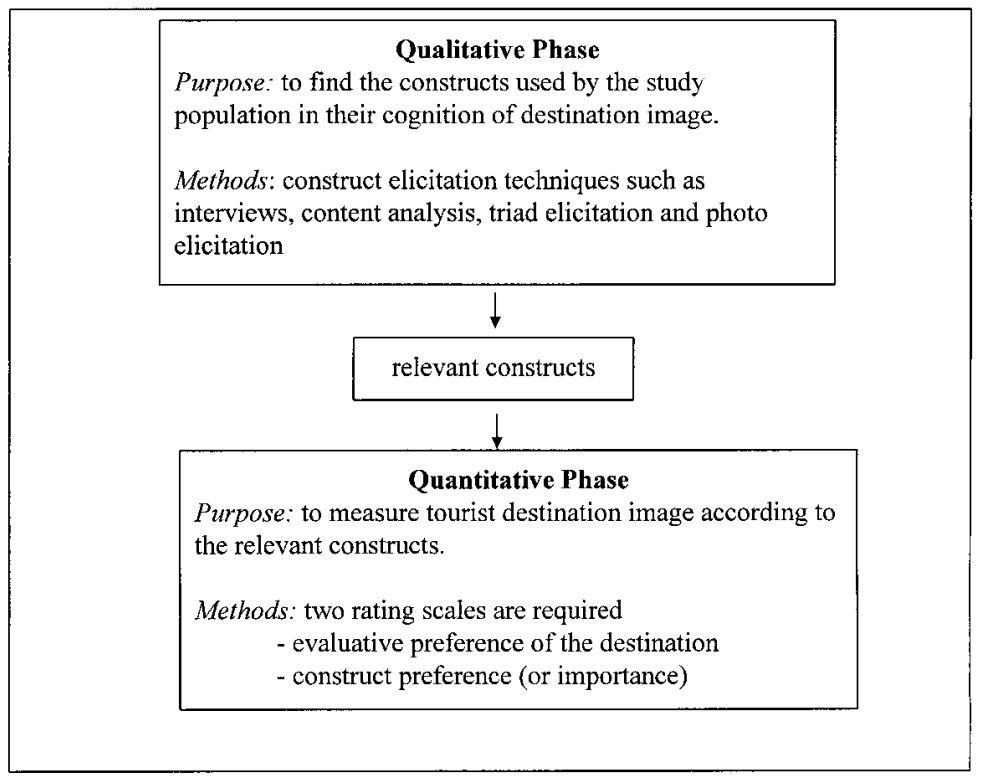

Figure 4. A model for destination image research.

their settings. Many studies in the field of environmental perception have used photographic media. Following a meta-analysis (which covered 11 previous relevant studies, 152 environments evaluated by 2400 respondents), Stamps (1990) found a correlation of 0.86 between preferences obtained in situ and preferences obtained through photographs. These results would tend to support the use of photographic stimuli, but very few image studies have done so.

Few published studies have used consumers to elicit the constructs or attributes used to investigate destination image. Future research might combine the two techniques (structured and unstructured) to achieve valid results. This involves expending considerable effort in the design stages, utilising unstructured techniques to elicit the relevant destination image attributes and dimensions and then using these in a structured way to investigate images. Figure 4 outlines a broad model for conducting destination image research which incorporates two phases of research. The first is a qualitative phase using unstructured methods to find the constructs relevant to the group being studied. The second phase draws upon the results of the first and measures the image quantitatively according to the constructs. The two phases are discussed in more Copyright (C) 1999 John Wiley \& Sons, Ltd. detail below.

\section{THE QUALITATIVE PHASE: CONSTRUCT ELICITATION}

The elicitation of constructs from the population being studied through qualitative research minimises the danger of forcing respondents to react to a standardised framework that may not be an accurate representation of their image. Until the early 1990s, few studies elicited the attributes, constructs or dimensions that were used for image measurement from the population being sampled through qualitative techniques. One of the earliest instances of construct elicitation was by Crompton (1979) who used content analysis of reading material, travel brochures and unstructured interviews with 36 students to determine the attributes used in a survey of American student's perception of Mexico. Content analysis and other techniques for construct elicitation are described below.

\section{Content analysis}

Content analysis of written information, such as guidebooks or visual information including photographs in travel brochures, can provide a great deal of information about

Int. J. Tourism Res. 1, 1-15 (1999) 
the images projected of tourist destinations. For example, Dilley (1986) analysed the images used by different national tourist organisations in projecting their destination to the North American market. Brochures from 21 countries were analysed and images were categorised according to the type of information conveyed. Dilley comments on the cliche of 'a picture being worth a thousand words', noting that over half the brochures gave over $75 \%$ of their space to pictures. He found there were clear regional patterns in the types of images projected, with brochures for 'old world' countries (e.g. Britain, India, Japan, Portugal) showing a clear dominance of history and art type images, brochures for islands (e.g. Bahamas, Trinidad and Tobago) showing pictures of recreational pursuits and coastal landscapes, with some islands focusing on the exotic with images of local people, history and art (e.g. Jamaica and Tahiti).

Content analysis can also be performed on other forms of communication, including information gathered through interactive interviews or focus groups. Interviews where respondents discuss their image of a destination are taped and transcribed, and then the important dimensions, constructs or attributes are extracted. The categorisation process needs to be transparent otherwise the researcher's own biases can be imbued in the results. A common method of ensuring transparency is to document the development of the categorisation system formulated by a team of researchers using a process of constant comparison, revision and modification to identify and code the specific dimensions and themes contained in the transcripts. Various tests for reliability, such as Scott's pi (Scott, 1955) are available to measure coding reliability between individual coders on the team and similar techniques can be adapted for individual researchers.

\section{Free elicitation}

Free elicitation, in the form of word-association, has been used widely in the field of marketing research. Its main use, however, has been for the assessment of motivations rather than construct elicitation. Reilly (1990), in an investigation of the image of Montana, asked

Copyright (C) 1999 John Wiley \& Sons, Ltd. respondents: 'What three words best describe the state of Montana as a destination for vacation or pleasure travel?' The respondents then provided three responses (or fewer, if they were unfamiliar with or unable to describe the destination). The responses were coded into similar categories and frequencies of the various types of responses recorded (Reilly, 1990, p. 20).

The main advantages of free elicitation for destination image research are that it allows the respondent to describe the target stimulus in terms that are salient to the individual, rather than responding to the researchers' predetermined image dimensions (Reilly, 1990, p. 22). Another advantage is that it will measure whether the image of a destination is lacking or weak, that is, if respondents are unable to provide responses. When combined with other techniques, the free elicitation technique is best used first because it offers a spontaneous 'window' on the image held by tourists. The lack of in-depth processing shown by the rapid reaction times and the high frequency of particular responses on free elicitation tasks indicate that this technique draws out parts of the easy-to-access stereotypical image.

\section{Triad elicitation}

Researchers have adapted Kelly's (1955) 'triad elicitation technique' to extract constructs about destinations (Riley and Palmer, 1976; Pearce, 1982; Botterill and Crompton, 1987, 1996; Botteril, 1988, 1989; Embacher and Buttle, 1989; Walmsley and Jenkins, 1993; Young, 1995). Following Kelly, constructs are essentially bipolar discriminations made by a person which represent their fundamental way of viewing the world (Bannister and Fransella, 1986, p. 27). In this paper, however, the term 'construct' is used loosely to refer to concepts or ideas that an individual uses to categorise image components rather than in the strictly bipolar sense of Kelly.

Triad elicitation involves the successive presentation of groups of three elements, which in a tourist context, are usually place names. The subject is asked to compare the three place names and explain a construct that makes two of the places similar, but separate

Int. J. Tourism Res. 1, 1-15 (1999) 
from the third, with the resulting reason known as a construct. For example, asked to compare London, Tokyo and Sydney, a respondent may say that London and Sydney are similar because the inhabitants speak English, while Tokyo is different because its inhabitants speak Japanese. The place names used as stimuli can be elicited from the respondent or provided by the researcher.

With a set of 12 elements there are numerous ways of presenting combinations of three elements to elicit constructs. In many uses of the approach, successive triad presentations are continued until no new constructs are elicited. For this reason the method can be very time-consuming and is highly dependant on the continual full cooperation of the subjects. Triad elicitation and its parent, the repertory grid technique, have been used by a number of researchers in the study of leisure, recreation and tourism (Riley and Palmer, 1976; Pearce, 1982; Botterill and Crompton, 1987, 1996; Botterill, 1989; Embacher and Buttle, 1989; Walmsley and Jenkins, 1993; Young 1995).

\section{Photo-elicitation}

Photo-elicitation, first described by Collier (1967), is a simple variation on open-ended interviewing where the interview is guided by images. These images are typically photographs that the researcher presents of the subject's world (Harper, 1994). Harper comments that this method is still to catch on as 'a frontline sociological method, yet its potential is nearly endless ... the well achieved photo elicitation interview really redefines the essential relationships of research.' (1994, p. 410).

Botterill and Crompton (1987, 1996) and Botterill $(1988,1989)$ have developed photoelicitation for investigating tourist experiences from the individual tourist's perspective. They combined the use of the repertory grid technique with visual images by using personal holiday snapshots and brochure photographs to elicit constructs pertaining to particular destination images. In the first study published (Botterill and Crompton, 1987), the researchers invited a tourist to explore her thinking about her Mexican vacation using six colour prints of scenes she had personally photographed. Using the triad procedure the

Copyright (C) 1999 John Wiley \& Sons, Ltd. tourist was asked to identify how two of the photographs are similar and yet different from the third. The resulting constructs showed her individual perception of Mexico based on her personal experiences. In a further study Botterill and Crompton (1996) explored the personal construct systems of two American tourists to Britain and how these changed before and after the tourist experience.

\section{Summary}

The types of constructs and the level of extractable information using construct analysis are variable according to the particular image that is being explored and the subject's familiarity with the image. Scott et al. (1978) outlined 14 different variable properties that could help to describe the relationships between constructs and their position in the cognitive structure. For example, the object complexity describes the number of ideas or constructs a person has about a particular object or destination, whereas attribute centrality relates to the frequency with which a particular construct is used by an individual. Scott's model also incorporates attitudes and opinions, for example, object valence is a measure of 'likeableness' for that destination. Attribute evaluation relates to the individual's opinion of an attribute (whether it is seen as positive, negative or neutral) with the direction altering depending on the context of the evaluation (e.g. cool weather may be considered a positive destination attribute for one destination, but negative for another).

The analysis of constructs can yield information about both the image and the people being interviewed (along with their cognitive structure). Most previous studies have focused on the image and have involved categorising the constructs according to their meaning. For example, Young (1995) used the categories 'evaluative', 'situational', 'permeable', 'vague', and 'impermeable' to describe construct types.

\section{THE QUANTITATIVE PHASE: MEASURING IMAGE}

Once the researcher has found the constructs, parameters or attributes that are used by a particular group of tourists in their cognition

Int. J. Tourism Res. 1, 1-15 (1999) 
Table 2. Attributes used by researchers to measure image

\begin{tabular}{|c|c|c|c|c|}
\hline \multirow[b]{2}{*}{ Attribute } & \multicolumn{4}{|c|}{ Number of studies measuring the attribute } \\
\hline & $\begin{array}{l}\text { Echter and } \\
\text { Ritchie, } 1991^{\mathrm{a}} \\
\quad(n=14)\end{array}$ & $\begin{array}{l}\text { Updated list } \\
\text { to } 1997^{b} \\
(n=6)\end{array}$ & $\begin{array}{l}\text { Australian } \\
\text { studies }^{c} \\
(n=8)\end{array}$ & $\begin{array}{c}\text { Total } \\
(n=28)\end{array}$ \\
\hline Scenery/natural attractions & 13 & 5 & 7 & 25 \\
\hline Hospitality/friendliness/receptiveness & 11 & 5 & 5 & 21 \\
\hline Climate & 8 & 4 & 6 & 18 \\
\hline Costs/price levels & 9 & 2 & 6 & 17 \\
\hline Nightlife/entertainment & 8 & 3 & 5 & 16 \\
\hline Sports facilities/activities & 8 & 2 & 5 & 15 \\
\hline Shopping facilities & 5 & 6 & 4 & 15 \\
\hline Personal safety & 4 & 3 & 7 & 14 \\
\hline Different cuisine/food/drink & 7 & 4 & 3 & 14 \\
\hline Restful/relaxing & 5 & 4 & 5 & 14 \\
\hline Historic sites/museums & 6 & 3 & 4 & 13 \\
\hline Accommodation facilities & 5 & 3 & 5 & 13 \\
\hline Different customs/culture & 7 & 2 & 4 & 13 \\
\hline Tourist sites/activities & 8 & 1 & 3 & 12 \\
\hline Local infrastructure/transportation & 7 & 2 & 2 & 11 \\
\hline National parks/wilderness areas & 7 & 1 & 2 & 10 \\
\hline Architecture/buildings & 7 & 2 & 1 & 10 \\
\hline Beaches & 6 & 0 & 3 & 9 \\
\hline Crowdedness & 4 & 2 & 2 & 8 \\
\hline Cleanliness & 4 & 1 & 3 & 8 \\
\hline Cities & 4 & 1 & 2 & 7 \\
\hline Accessibility & 2 & 2 & 3 & 7 \\
\hline Opportunity for adventure & 3 & 0 & 4 & 7 \\
\hline Facilities for information/tours & 1 & 1 & 4 & 6 \\
\hline Atmosphere (familiar versus exotic) & 4 & 0 & 2 & 6 \\
\hline Economic development/affluence & 3 & 0 & 2 & 5 \\
\hline Family or adult oriented & 1 & 1 & 3 & 5 \\
\hline Opportunity to increase knowledge & 2 & 0 & 2 & 4 \\
\hline Quality of service & 1 & 1 & 2 & 4 \\
\hline Fairs/exhibitions/festivals & 2 & 1 & 0 & 3 \\
\hline Extent of commercialisation & 1 & 0 & 2 & 3 \\
\hline Political stability & 1 & 1 & 1 & 3 \\
\hline Fame/reputation/fashion & 1 & 0 & 2 & 3 \\
\hline Degree of urbanisation & 1 & 0 & 1 & 2 \\
\hline Friends and relatives & & 1 & 2 & 3 \\
\hline Wildlife & & 0 & 3 & 3 \\
\hline Sophistication & & 0 & 2 & 2 \\
\hline Interesting & & 0 & 2 & 2 \\
\hline Busy/exciting & & 0 & 2 & 2 \\
\hline Local people & & 1 & 1 & 2 \\
\hline
\end{tabular}

${ }^{a}$ Echtner and Ritchie $(1991,10)$. Contains summary of 14 studies up to 1990 (Hunt, 1975; Crompton, 1977, 1979; Goodrich, 1978; Pearce 1982, Haahti and Yavas 1983, Crompton and Duray 1985, Kale and Weir, 1986; Phelps, 1986; Tourism Canada, 1986; Gartner and Hunt, 1987; Richardson and Crompton, 1988; Gartner, 1989; Calantone et al., 1989; Reilly, 1990).

${ }^{\mathrm{b}}$ Developed for this research. Contains summary of six international image studies not included in Echtner and Ritchie's study (Mansfield, 1987; Ohm and Chan, 1990; Ahmed, 1991; Chon, 1991, 1992; Weiler, 1991). ${ }^{\circ}$ Developed for this research. Contains summary of eight Australian image studies (Ross, 1994; Walmsley and Jenkins, 1993; Young, 1995; ATC, 1995, QTTC, 1995; Chalip and Green 1996, Waitt 1996, Murphy 1996). 
Table 2. Continued.

\begin{tabular}{|c|c|c|c|}
\hline Small towns & 0 & 2 & 2 \\
\hline Authenticity & 1 & 1 & 2 \\
\hline Language spoken & 0 & 2 & 2 \\
\hline Quality of merchandise & 0 & 2 & 2 \\
\hline Racial prejudice & 0 & 1 & 1 \\
\hline Water activities & 1 & 0 & 1 \\
\hline Wide open spaces & 0 & 1 & 1 \\
\hline Theme parks & 0 & 1 & 1 \\
\hline
\end{tabular}

and perception of tourist destination image, it is possible to use more structured methods to measure directly the images held by individuals. Measurement could involve asking the tourists to rate certain destinations according to the attributes distilled earlier. Previous studies have tended to use five- or seven-point Likert or semantic differential scaling techniques.

Echtner and Ritchie (1991) compiled a list of the attributes used by 14 researchers to measure destination image (see column 1, Table 2). The constructs measured most commonly were scenery/natural attractions, friendliness/hospitality/receptiveness, costs/ price levels, climate, tourist sites/activities, night life/entertainment and sports facilities and activities. Within the studies summarised by Echtner and Ritchie, a number of different sampling frames and populations were used. Some studies examined the images held by tourists (Pearce, 1982; Phelps, 1986; Reilly, 1990), whereas others studied the images held by potential tourists, such as students (Crompton, 1979) and American Express Cardholders (Goodrich, 1978). Also, a number of different spatial scales were incorporated into the studies. They ranged from studies examining the image of one destination (Phelps, 1986), such as a State (Crompton and Duray, 1985; Reilly, 1990), whereas others examined multiple destinations such as a group of States (Hunt, 1975; Gartner, 1989), a country (Crompton, 1977, 1979; Kale and Weir, 1986; Tourism Canada, 1986), or a group of countries (Pearce, 1982; Haahti and Yavas, 1983; Richardson and Crompton, 1988; Calantone et al., 1989). Thus the characteristics of the population sampled, and the geographic scale of the image that is being measured are likely to influence the

Copyright (C) 1999 John Wiley \& Sons, Ltd. image held by individuals, both in terms of the importance (or salience) of certain attributes and the evaluation of these attributes.

In Table 2, the author has expanded Echtner and Ritchie's review to include recent image studies (see column 3, Table 2) as well as studies that specifically investigated the image of Australian tourist destinations (see column 4, Table 2). This involved examining the attributes used in a further 14 image studies, some of which elicited the attributes from the tourist population whereas others were based on previous research or on the judgements of experts or the researchers themselves. The final column shows that the attributes measured most commonly in the 28 studies were scenery and natural attractions, friendliness and hospitality of local people and climate.

In recent non-Australian studies, the attribute measured most commonly was shopping facilities, whereas in the Australian studies the attributes measured most commonly were scenery and natural attractions and personal safety, followed by climate, and then costs and price levels. Some attributes that were measured only in Australian studies were wildlife, sophistication, small towns, and language spoken.

Two Australian studies of the destination image of the North Coast of New South Wales (Walmsley and Jenkins, 1993; Young, 1995) introduced several new attributes at the psychological end of Echtner and Ritchie's psychological-functional dimension, including 'appealing', 'interesting/not boring' and 'trendy/ in vogue'. Another Australian study, this time by Ross (1993), focused specifically on backpacker tourists. Ross commented that 'it is possible that members of this group do have distinct and identifiable images which

Int. J. Tourism Res. 1, 1-15 (1999) 
may be quite different from those of other traveller segments' (Ross, 1993, p. 55). However, the constructs or attributes that Ross used to assess image were distilled from a literature review of early image studies rather than from backpackers themselves. Thus, future research should involve construct elicitation from the population being studied.

When it comes to actually using the attributes to measure the images held by tourists of a particular place, there are two important aspects of the rating process. First, the respondent can evaluate the place according to a particular construct (e.g. 'How do you rate Hong Kong in terms of scenic beauty on a scale where 1 is "not at all beautiful" and 7 is "very beautiful" '). This rating is called the evaluative perception. Second, the respondent rates the salience or importance of the actual construct to himself or herself (e.g. 'How important is scenic beauty in your personal travel decisionmaking? Please rate on the following scale where 1 is "not at all important" and 7 is "very important" '). This second rating is called the construct preference.

The combination of the two scales (evaluative perception and construct preference) allows the researcher to understand the image held of particular destinations by individual tourists. It also enables the researcher to assign weights to those aspects of image that are considered important by a particular individual or group of individuals. The construct preference ratings also allow the distillation of market segments according to travel preferences. The aggregate or 'stereotyped' image of one place can be compared with the image of another place within these market segments. The measurement of image in this way also allows the researcher to observe changes in image over time due to travel experiences (see Weiler, 1989).

Fishbein's (1963) value-expectancy model is useful for combining the two types of measurements into a single measure, 'attitude'. According to Fishbein, an individual's attitude towards a destination is equal to his strength of belief about (or preference for) each attribute of a destination multiplied by the importance or salience that he or she assigns to that attribute. Thus, in calculating a person's attitude towards a destination, the results of the two

Copyright (C) 1999 John Wiley \& Sons, Ltd. rating scales are multiplied together. Weiler (1989) used Fishbein's model to compare Japanese student tourists' attitudes before and after travel to British Columbia, Canada. Her results showed that the perceptions of very few attributes changed significantly following experience of the destination. Weiler noted that due to the nature of Fishbein's model, positive and negative perception changes can easily cancel each other out in the final calculation of image change. Such cancelling, however, can be monitored and accounted for by conducting separate analyses on the two measurement scales and by using multiple and complementary data collection methods and instruments (Weiler, 1989, p. 307).

\section{Analysis of the data}

There are numerous ways of analysing the data collected through image assessment studies and only a very brief description is offered here. Often a simple descriptive analysis of aggregated data (e.g. the mean rating and standard deviation of a particular attribute over a certain market segment) will go a long way in providing useful marketing information, such as the stereotyped images of places held by individuals and groups. Multivariate analyses using statistical packages, such as SPSS, which provide statistical procedures including cluster analysis, factor analysis, principle components analysis, and multidimensional scaling, provide a more sophisticated analysis. As in any research, the type of statistical analysis chosen should be based on its appropriateness for the research question being investigated and the nature of the data being analysed. In many image studies, a combination of statistical methods have been used, including factor analysis followed by multidimensional scaling. Using several different techniques adds to the validity if there is convergence between the results achieved using different analyses.

\section{CONCLUSION}

As the global tourist industry expands to become an increasingly important part of international trade, countries such as Australia 
are competing in the international marketplace to attract tourists. The recipe for a country's attraction (e.g. Australia's reliance on the natural and scenic attractions) needs to be reevaluated taking into account changing patterns of tourism flows, such as the expansion of Pacific Rim countries as sources for tourists, and recent growth in new market sectors such as 'backpackers'. There is a need to investigate whether the images of countries projected to the world and perceived by international tourists and potential tourists are the most appropriate for new markets.

This paper has reviewed the current understanding of the concept of tourist destination image and the research methods available for measuring image. The two-phase, destinationimage research model presented in this paper suggests that future research needs to be based first on sound qualitative research that provides the constructs relevant to the market being studied, and second, in the quantitative stage, the research needs to take into account the level of importance of these constructs to different individuals and groups. This general model is not new. It is widely recognised in the social sciences that quality research comes from combining qualitative and quantitative methods. However, past research into destination image has often neglected the initial qualitative stage and has favoured structured methods containing categories often based on the researcher's opinions or those found in the literature without testing to see if these are the most relevant to the group being studied.

\section{REFERENCES}

Ahmed, Z. (1991), The influence of the components of a State's tourist image on product positioning strategy, Tourism Management, December, 331340.

ATC (1992), Asia, Europe, Japan Market Segmentation Studies: Executive Summary. Sydney: Australian Tourist Commission.

Bannister, D., and Fransella, F. (1986), Inquiring Man: Psychology of Personal Constructs, 3rd ed. Beckenham: Croom Helm.

Botterill, T. D. (1988), Experiencing vacations: personal construct psychology, the contemporary tourist and the photographic image. Texas A and M University Texas: Unpublished PhD Thesis.

Botterill, T. D. (1989), Humanistic tourism? Personal

Copyright (C) 1999 John Wiley \& Sons, Ltd. constructions of a tourist: Sam visits Japan, Leisure Studies, 8, 281-293.

Botterill, T. D., and Crompton, J. L. (1987), Personal constructions of holiday snapshots, Annals of Tourism Research, 14, 152-156.

Botterill, T. D., and Crompton, J. L. (1996), Two case sudies exploring the nature of the tourist's experience, Journal of Leisure Research, 28 (1), 5782.

Calantone, R. J., Bennetto, C. A., and Bojanic, D. C. (1989), Multinational tourism positioning using correspondence analysis, Journal of Travel Research, 28(2), 25-32.

Chalip, L., and Green, B. C. (1996), Design of the Destination Image Scale. Queensland Tourist Travel Corporation (QTTC), unpublished report.

Chon, K. S. (1990), The role of destination image in tourism: a review and discussion, The Tourist Review, 2, 2-9.

Chon, K. S. (1991), Tourism destination image modification process - marketing implications, Tourism Management, 12, 68-72.

Chon, K. S. (1992), The role of destination image in tourism: an extension, The Tourist Review, 2, 2-7.

Collier, J. (1967), Visual Anthropology: Photography as a Research Method. New York: Holt, Reinhart and Winston.

Craik, K. H. (1971), The assessment of places, in McReynolds, P. (Editor), Advances in Psychological Assessment: Science and Behaviour, Vol. 2. California: Palo Alto, 40-62.

Crompton, J. L. (1977), A systems model of the tourist's destination selection process with particular reference to the role of image and perceived constraints. College Station, Texas: Texas A and M University Unpublished PhD Dissertation.

Crompton, J. L. (1979), An assessment of the image of Mexico as a vacation destination and the influence of geographical location upon that image, Journal of Travel Research, 17(4), 18-23.

Crompton, J. L., and Duray, N. A. (1985), An investigation of the relative efficacy of four alternative approaches to importance-performance analysis, Journal of the Academy of Marketing Sciences, 13(4), 69-80.

Dilley, R. S. (1986), Tourist brochures and tourist images, The Canadian Geographer, 30(1), 59-65.

Echtner, C. M., and Ritchie, J. R. B. (1991), The meaning and measurement of destination image, Journal of Travel Studies, 2(2), 2-12.

Embacher, J., and Buttle, F. (1989), A repertory grid analysis of Austria's image as a summer vacation destination, Journal of Travel Research, 27, 3-7.

Fishbein, M. (1963), An investigation of the relationships between beliefs about an object and the

Int. J. Tourism Res. 1, 1-15 (1999) 
attitude toward that object, Human Relations, 16, 233-40

Gartner, W. C. (1989), Tourism image: attribute measurement of state tourism products using multi-dimensional scaling techniques, Journal of Travel Research, 28(2), 16-20.

Gartner, W. C., and Hunt, J. D. (1987), An analysis of state image change over a twelve year period (1971-1983), Journal of Travel Research, 16(2), 1519.

Goodrich, J. N. (1978), New approach to image analysis through multi-dimensional scaling, Journal of Travel Research, 17(4), 3-7.

Gunn, C. A. (1972), Vacationscape-Designing Tourist Regions. Austin, Texas: University of Texas.

Haahti, A., and Yavas, U. (1983), Tourist's perception of Finland and selected European countries as travel destinations, European Journal of Marketing, 12(2), 34-42.

Harper, D. (1994), On the authority of the image; visual methods at the crossroads, in Denzin, N. K., and Lincoln, Y. S. (Editors), Handbook of Qualitative Research. California: Sage Publications, 403-412.

Hunt, J. D. (1975), Image as a factor in tourism development, Journal of Travel Research, 13, 1-7.

Jenkins, O. H. (1993), Marketing and the ecotourism paradox. Sydney: University of Sydney Honours Thesis, submitted in partial fulfilment of the Bachelor of Economic (Social Sciences), Department of Geography.

Jenkins, O. H., and McArthur, S. (1996), Marketing Protected Areas, Australian Parks and Recreation, 32(4), 10-15.

Kale, S., and Weir, K. M. (1986), Marketing third world countries to the Western traveller: the case of India. Journal of Travel Research, 25(2), 2-7.

Kelly, G. A. (1955), The Psychology of Personal Constructs. London: Routledge.

Lawson, F., and Baud-Bovy, M. (1977), Tourism and Recreational Development. London: Architectural Press.

MacInnis, D. J., and Price, L. L. (1987), The role of imagery in information processing: review and extension, Journal of Consumer Research, 13, 473491.

Mansfield, Y. (1987), The choice of destination made by tourists and its impact on their spatial behaviour. London: London School of Economics $\mathrm{PhD}$ Dissertation, Geography Department.

Mayo, E. J. (1973), Regional images and regional travel behaviour, in The fourth annual conference proceedings of the Travel Research Association, Research for Changing Travel Patterns: Interpretation and Utilisation, August 12-15, 1973, 211-218.

Mayo, E. J. (1975), tourism and national parks: a psychographic and attitudinal study, Journal of Travel Research, 14, 14-18.

Mercer, D. (1971), The role of perception in the recreational experience: a review and discussion. Journal of Leisure Research, 3, 261-276.

Murphy, L. (1996), Backpackers and the Decisions They Make. Townsville: James Cook University, Department of Tourism.

Narayana, C. L. (1976), The stability of perceptions, Journal of Advertising Research, 16(2), 45-49.

Nolan, D. (1976), Tourist's use and evaluation of travel information, Journal of Travel Research, 14, 68.

Ohm, Y., and Chan, C. F. (1990), Hong Kong as a travel destination in South East Asia: a multidimensional approach, Tourism Management, 11(1), 123-132.

Pearce, P. L. (1982), Perceived changes in holiday destinations, Annals of Tourism Research, 9(2), 145164.

Pearce, P. L. (1988), The Ulysses Factor: Evaluating Visitors in Tourist Settings. New York: SpringerVerlag.

Pearce, P. L., and Black, N. (1996), The simulation of tourist environments: methodological perspectives for enhancing tourism research, in Proceedings of the Australian Tourism and Hospitality Research Conference, Australian and International Perspectives, Coffs Harbour: Bureau of Tourism Research.

Phelps, A. (1986), Holiday destination image - the problem of assessment, Tourism Management, 7(3), 168-180.

Pizam, A., Neumann, Y., and Reichel, A. (1978), Dimensions of tourist satisfaction with a destination area. Annals of Tourism Research, 5(3), 314-322.

QTTC (1995), Sunshine Coast Holiday Destination Survey. Brisbane: Queensland Tourist and Travel Corporation (QTTC), Unpublished questionnaire.

Reilly, M. D. (1990), Free elicitation of descriptive adjectives for tourism image assessment, Journal of Travel Research, 28(4), 69-76.

Richardson, S. L., and Crompton, J. L. (1988), Cultural variations in perceptions of vacation attributes, Tourism Management, 9 (June), 128-136.

Riley, S., and Palmer, J. (1976), Of attitudes and latitudes: a repertory grid study of perceptions of seaside resorts, in Slater, P. (Editor), Measurements of Intrapersonal Space. Chichester: Wiley, 153-164.

Ross, G. F. (1993), Ideal and actual images of backpacker visitors to Northern Australia, Journal of Travel Research, 21(3), 54-57.

Ross, G. F. (1994), The Psychology of Tourism. Melbourne: Hospitality Press.

Scott, D. R., Schewe, C., and Frederick, D. (1978), A 
multi-brand/multi-attribute model of tourist state choice, Journal of Travel Research, 17(3), 23-29.

Scott, W. A. (1955), Reliability of content analysis: the case of nominal scale coding. Public Opinion Quarterly, 19, 321-325.

Selby, M., and Morgan, N. J. (1996), Reconstruing place image - a case-study of its role on destination market research, Tourism Management, 17(4), 287-294.

Stabler, M. J. (1988), The image of destination regions: theoretical and empirical aspects, in Goodall, B. and Ashworth, G. (Editors), Marketing in the Tourism Industry - the Promotion of Destination Regions. London: Routledge, 133-159.

Stamps III, A. E. (1990), Use of photographs to simulate environments: a meta-analysis, Perceptual and Motor Skills, 71, 907-913.

Timmermans, H., Van Er Heijden, R., and Westerveld, H. (1982), The identification of factors influencing destination choice: an application of the Repertory Grid methodology, Transportation, 11, 189-203.
Tourism Canada (1986), Pleasure Travel Markets to North America and United Kingdom, Toronto: Tourism Canada.

Van Raaj, W. F., and Francken, D. A. (1984), Vacation decisions, activities and satisfaction, Annals of Tourism Research, 11, 101-112.

Waitt, G. (1996), Korean student's assessment of Australia as a holiday destination, Australian Geographer, 27(2), 249-269.

Walmsley, D. J., and Jenkins, J. M. (1993), Appraisive images of tourist areas: application of personal constructs, Australian Geographer, 24(2), 1-13.

Weiler, B. (1989), The effects of international travel on the tourist: seeing and clearing methodological roadblocks, GeoJournal, 19(3), 303-307.

Whynne-Hammond, C. (1985), Elements of Human Geography. London: George Allen and Unwin.

Young, M. (1995), Evaluative constructs of domestic tourist places, Australian Geographical Studies, 33(2), 272-286. 